Others asserted that the earth made man. Look at the facts, said Marsh. Man cuts down trees, clears and tills the soil, dams rivers; all these things Marsh had done himself. Was the landscape the same afterward? Did streams flow as before? Were plants, fish, birds, animals unchanged in form and numbers? Assuredly not. Where such activities had long gone on the changes were profound and often ruinous.

Anyone wielding a hoe or an ax knows what he is doing, but before Marsh no one had assessed the cumulative effect of all axes and hoes. For him the conclusion was inescapable. Man depends upon soil, water, plants, and animals. But in obtaining them he unwittingly destroys the supporting fabric of nature. Therefore man must learn to understand his environment and how he affects it. For his own sake, not for nature's alone, man must restore and maintain it as long as he tenants the earth.

\title{
A Note on the Text
}

The text used here is the first edition, as published in New York by Charles Scribner in 1864. This is the edition that had the greatest impact, and its centenary deserves commemoration.

Man and Nature was published simultaneously in London by Sampson Low, Son, and Marston, almost without alteration. The New York edition was reprinted at least once in 1865 and again in 1867, 1869, and 1871, all printings from 1867 on incorporating a 17-page appendix of some 65 additions to the text and footnotes. It is not known how many copies of this or of later editions were printed or sold.

An 1869 edition in Italian was destroyed and another published in Florence in 1872, the first translation, Marsh noted in an attached manuscript, having been "made by a lady not acquainted with the subject, and with a very imperfect knowledge of both English and Italian. The gross and often ludicrous errors . . . [number] not less than 6,000 , or 10 to a page." A French translation contracted for by Elisée Reclus was not completed, partly because it did not meet Marsh's exacting standards.

The second Italian edition provided the framework for the second American and English editions, in 1874, retitled The Earth as Modified by Human Action: a New Edition of Man and Nature. Marsh reorganized chapter subdivisions, corrected a few errors; deleted some passages, and worked in the 1867 appendix together with a substantial amount of new material; the second is 95 pages 
longer than the first edition. It was reprinted in 1877, with 44 additional notes in a 15-page appendix.

Material from this appendix and from other new sources appears in the body of the third edition, published posthumously in New York in 1885. It was reprinted in 1898 and 1907.

The second and third editions contain a copious amount of new data and are better organized than the first, but Marsh's conclusions remained substantially as he first expressed them. Material changes and corrections in the later printings and editions are summarized in square brackets in the footnotes of the present volume.

The original text and footnotes have otherwise been altered only as follows:

(1) Quotations originally written in English but retranslated by Marsh from foreign translations are corrected back to the original sources.

(2) Insignificant errors in Marsh's quotations from sources in English are silently corrected, as are the obvious misprints in his own text.

(3) Modern botanical nomenclature is added in square brackets, or supplied where none was given, in accordance with Harlan P. Kelley and William A. Dayton, Standardized Plant Names (Harrisburg, Pa., 1942); animal names are similarly modernized.

(4) Place names are respelled where Marsh's rendering might seem obscure, and the modern equivalents are given where names have since been changed. Place names which could not be located remain as in the original.

(5) Bibliographical details in the text are occasionally transferred to the notes.

(6) Centered headings and contents summaries are matched or supplied to correct major discrepancies.

(7) Marsh's own citations are silently corrected and completed. Other citations and material added by the present editor appear in square brackets; however, unless otherwise noted, bracketed insertions in quoted material are Marsh's own editorial notes.

All references and quotations have been checked for accuracy and completeness with the 319-item "Bibliographical List of Works Consulted" published with the 1864 edition, but which accounts for only half the actual citations; with the Catalogue of the Library of George Perkins Marsh, compiled by H. L. Koopman (Burlington, Vt., 1892); and when possible with Marsh's own 
library, which remains virtually intact at the Wilbur Library of the University of Vermont, for which it was bought in 1882 by Frederick Billings. For the opportunity to use this unique collection of some 12,500 books and pamphlets and for much assistance and encouragement I am indebted to T. D. Seymour Bassett.

May 1964

David Lowenthal 
